\title{
SYSTEMIC LUPUS ERYTHEMATOSUS WITH UNUSUAL MANIFESTATIONS
}

\author{
Lorena Manea ${ }^{1}$, Cătălin Mihai Popescu², Raluca Popescu², Daniela Adriana Ion², \\ Andreea Alexandra Nicola ${ }^{1}$, Paul Miron-Basalic ${ }^{1}$, Mădălina Duna $^{1}$, Simona Enache ${ }^{1}$, \\ Lucia Radu¹, Florina Nițu1, Laura Groșeanu ${ }^{1,2}$, Denisa Predețeanu1,2 \\ "Sf. Maria" Clinical Hospital, Bucharest, Romania \\ University of Medicine and Pharmacy, "Carol Davila", Bucharest, Romania \\ Corresponding author: \\ Lorena Manea MD \\ e-mail: Ior.zeiler@gmail.com; Tel: +40721139487
}

\begin{abstract}
Systemic lupus erythematosus (SLE) is a chronic autoimmune disease of unknown etiology, presenting with variable clinical picture. Having a high heterogeneity and lacking pathognomonic features, very often the diagnosis poses a great challenge for the clinician. Several unusual clinical manifestations such as nasal septal perforation and digital gangrene can occur in LES patients.
\end{abstract}

Case report. We report the case of a 42-year-old woman, known with SLE, hospitalized in our department for a clinical presentation consisting of a recent major epistaxis, physical asthenia and acral necrosis of the upper limbs. Physical examination revealed an afebrile patient, with a cushingoid facies, facial telangiectasias, and necrotic scars localized on the distal phalanges, bilaterally.

A diagnostic nasal endoscopy showed a large septal perforation with the absence of the cartilaginous nasal septum. CT highlighted an extended defect at the level of the cartilaginous part of the nasal septum.

Conclusion. Nasal septal perforation remains an underdiagnosed invalidating complication of lupus and treated and discovered early could have an important impact on the general health of an already burdened by disease patient.

Keywords: systemic lupus erythematosus, nasal septal perforation, digital gangrene.

\section{Rezumat}

Lupusul eritematos sistemic (LES) este o boală cronică autoimună de etiologie necunoscută, care prezintă un tablou clinic variabil. Heterogenitatea mare și lipsa semnelor clinice patognomonice fac, adesea, ca stabilirea diagnosticului să fie o provocare pentru clinician. La pacienții cu LES pot apărea manifestări clinice neobișnuite, cum ar fi perforația septului nazal și gangrena digitală. 


\section{INTERNAL}

Clinical Cases.

Prezentarea cazului. Raportăm cazul unei femei de 42 de ani, cunoscută cu LES, internată în secția noastră pentru un episod recent de epistaxis major, astenie fizică și necroză acrală a membrelor superioare. Examenul fizic a relevat o pacientă afebrilă, cu facies cushingoid, telangiectazii faciale și cicatrici necrotice la nivelul falangelor distale, bilateral.

Endoscopia nazală diagnostică a arătat o perforație septală importantă, cu absența septului nazal cartilaginos. Tomografia computerizată a evidențiat un defect extins la nivelul părții cartilaginoase a septului nazal.

Concluzie. Perforația septului nazal rămâne una dintre complicațiile invalidante ale lupusului care sunt subdiagnosticate și al căror diagnostic și tratament precoce ar putea avea un impact important asupra sănătății generale a unui pacient deja împovărat de boală.

Cuvinte cheie: lupus eritematos sistemic, perforație septală nazală, gangrenă digitală.

\section{Introduction}

Systemic lupus erythematosus (SLE) is a chronic autoimmune disease of unknown etiology, presenting with variable clinical picture, from mild to severe forms. Having a high heterogeneity and lacking pathognomonic features, very often the diagnosis poses a great challenge for the clinician $^{(1)}$.

Clinical and laboratory findings act as guidance when making the diagnosis. Antidouble-stranded DNA [anti-dsDNA] and antiSmith [anti-Sm]) antibodies are highly associated with this condition. The patient can experience constitutional symptoms such as fatigue, fever, or weight loss. Myalgia and arthritis with arthralgias occur early in the disease process. Mucocutaneous involvement has a high variability, the most common skin manifestation is the presence of erythema in a malar distribution. Regarding vascular manifestations, Raynaud phenomenon occurs in approximatively 50\% of patients with SLE and small vessel vasculitis is frequently encountered. Renal and gastrointestinal involvement are common manifestations. Pulmonary manifestations of SLE can include pneumonitis, pleuritis, interstitial lung disease and pulmonary hypertension. Hematologic abnormalities such as pancytopenia and anemia of chronic disease are common ${ }^{(2,3,4)}$.

Several unusual clinical manifestations such as nasal septal perforation, pulmonary 
arterial hypertension (PAH) and digital gangrene can occur in LES patients. A rare complication of the disease with only a few cases reported in the literature is the nasal septal perforation. The mechanism of septal perforation in SLE is thought to be attributed to inflammation, ischemia, and ulceration with chondrolysis. The disease occurs during LES exacerbations, epistaxis being a frequent complaint $^{(5)}$. An association between anti-RNP antibodies and Raynaud's phenomenon has been reported. The etiology of digital gangrene in SLE is complex. The presence of antiphospholipid syndrome (APS), overlap syndrome, atherosclerosis or vasculitis, are potential causes for digital ulcers and necrosis in LES patients ${ }^{(6)}$.

$\mathrm{PAH}$ is a rare complication of SLE and is considered to be more frequently associated with systemic sclerosis (SSc) or mixed connective tissue disease (MCTD). Raynaud's phenomenon, digital gangrene, cutaneous vasculitis and livedo reticularis were demonstrated to be associated with $\mathrm{PAH}^{(7,8)}$.

The reported case illustrates these uncommon manifestations as well as their clinical management.

\section{Case report}

We report the case of a 42-year-old woman, known with SLE, hospitalized in our department for a clinical presentation consisting of a recent major epistaxis, physical asthenia and acral necrosis of the upper limbs (distal phalanges II, III right hand and I, V left hand).

The disease began 20 years ago with fever, migraines, emesis, and poor general condition, for which the family doctor recommended standard blood tests, considering enterocolitis as the most likely cause of symptoms. The $\mathrm{CBC}$ revealed anemia $(9 \mathrm{~g} / \mathrm{dl})$, leukopenia $(3900 / \mathrm{mm} 3)$ and thrombocytopenia (120000), as well as inflammatory nonspecific syndrome. Considering the presence of pancytopenia, the patient was then referred to the Hematology Department, where a bone marrow aspirate was performed, showing LE cells and the suspicion of SLE was raised.

The patient started experiencing sudden onset of cold fingers in association with the presence of skin pallor followed by cyanotic skin and erythema after rewarming (Raynaud's phenomenon).

The patient complained of migratory, symmetrical, polyarticular arthralgias, involving the carpal, metacarpophalangeal and interphalangeal joints, with fever and poor general condition. The patient was then referred to Rheumatology for additional evaluations. The laboratory tests performed showed positive lupus autoimmunity (ANAs, anti dsDNA, anti Sm and anti Ro-SSA) as well as anti-U1 RNP antibodies, but negative for APS panel. Blood analysis showed persistent pancytopenia, elevated acute phase reactants and urinalysis detected proteinuria (600mg/24h). The clinical picture began to be consistent with lupus systemic damage and the diagnosis of SLE with articular, hematological, renal, and immunological manifestations was made.

In 2001, considering the presence of lupus nephritis the patient was treated with $1 \mathrm{~g}$ intravenous pulse Cyclophosphamide (6 perfusions), and shortly after, the disease was considered to be in remission. The patient was prescribed $400 \mathrm{mg}$ Hydroxychloroquine and low dose systemic corticosteroids (initially $60 \mathrm{mg}$ daily, then tapered to $10 \mathrm{mg}$ daily), and for the following 11 years the disease was reported to be stable, but without any medical documents to confirm it. 


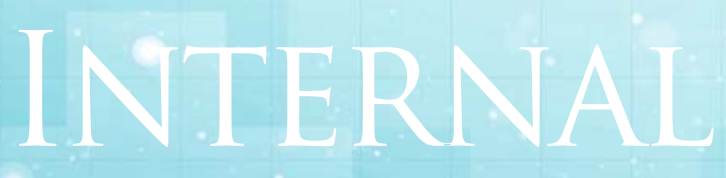

Clinical Cases.

In 2015, the patient's condition began to worsen and several admissions were made. $A$ routine chest $x$-ray revealing enlarged pulmonary arteries led to suspicion of PAH. The transthoracic echocardiogram revealed PAH with mean pulmonary artery pressure measuring $40 \mathrm{mmHg}$ with pulmonary regurgitation class grade 2 . To confirm the diagnosis, a right heart catheterization was performed, with mean pulmonary artery pressure measuring $36 \mathrm{mmHg}$ (baseline) and systolic pulmonary artery pressure measuring $60 \mathrm{mmHg}$. The diagnosis of Precapillary PAH was made. The patient was prescribed treatment with a vasodilator: oral phosphodiesterase 5 inhibitor (sildenafil, 60 mg daily).

Taking into account the presence of lupus nephritis, in 2016, the patient was administered $1 \mathrm{~g}$ intravenous pulse Cyclophosphamide (6 perfusions) with favourable response; the renal biopsy performed during the same year showing inactive lupus nephritis. After the treatment with Cyclophosphamide the patient was treated with Hydroxychloroquine and Mycophenolate mofetil.

During the course of the disease, the patient experienced many Raynaud's episodes, aggravated by cold and psychological stress with necrosis of the distal phalanges II, III right hand and I, V left hand, for which several surgical consultations were performed.
For regular check-up reasons, a chest x-ray (revealing enlarged pulmonary arteries) transthoracic Doppler echocardiography, hands $\mathrm{x}$-ray and arterial Doppler echography of the upper limbs were carried out in June 2020, one month prior the present hospitalization.

It is worth mentioning that during her lifetime, the patient experienced multiple episodes of epistaxis, but without major implications on her overall health. Several admissions to the ENT department (complaints regarding epistaxis, nasal pressure and discomfort and also with a history of local superinfection) were made.

Two days before the current admission to the hospital, the patient experienced a major episode of epistaxis, without a traumatic cause. The patient addressed to the ER and a nasal intracavitary dressing was performed. The double antiplatelet therapy with clopidogrel and low-dose aspirin was temporally interrupted and a prophylactic antibiotic therapy was administered.

Physical examination revealed an afebrile patient, with a cushingoid facies, facial telangiectasias, and necrotic scars localized on the distal phalanges, bilaterally (figure 1). Abnormal laboratory findings included a mild normochromic, normocytic anaemia (Haemoglobin $=10.3 \mathrm{~g} / \mathrm{dl}$ ), elevated ESR and CRP (ESR $=116 \mathrm{~mm} / \mathrm{h}$ and $\mathrm{CRP}=8.48 \mathrm{mg} / \mathrm{L}$ ), proteinuria per $24 \mathrm{~h}(891.21 \mathrm{mg} / 24 \mathrm{~h})$, 


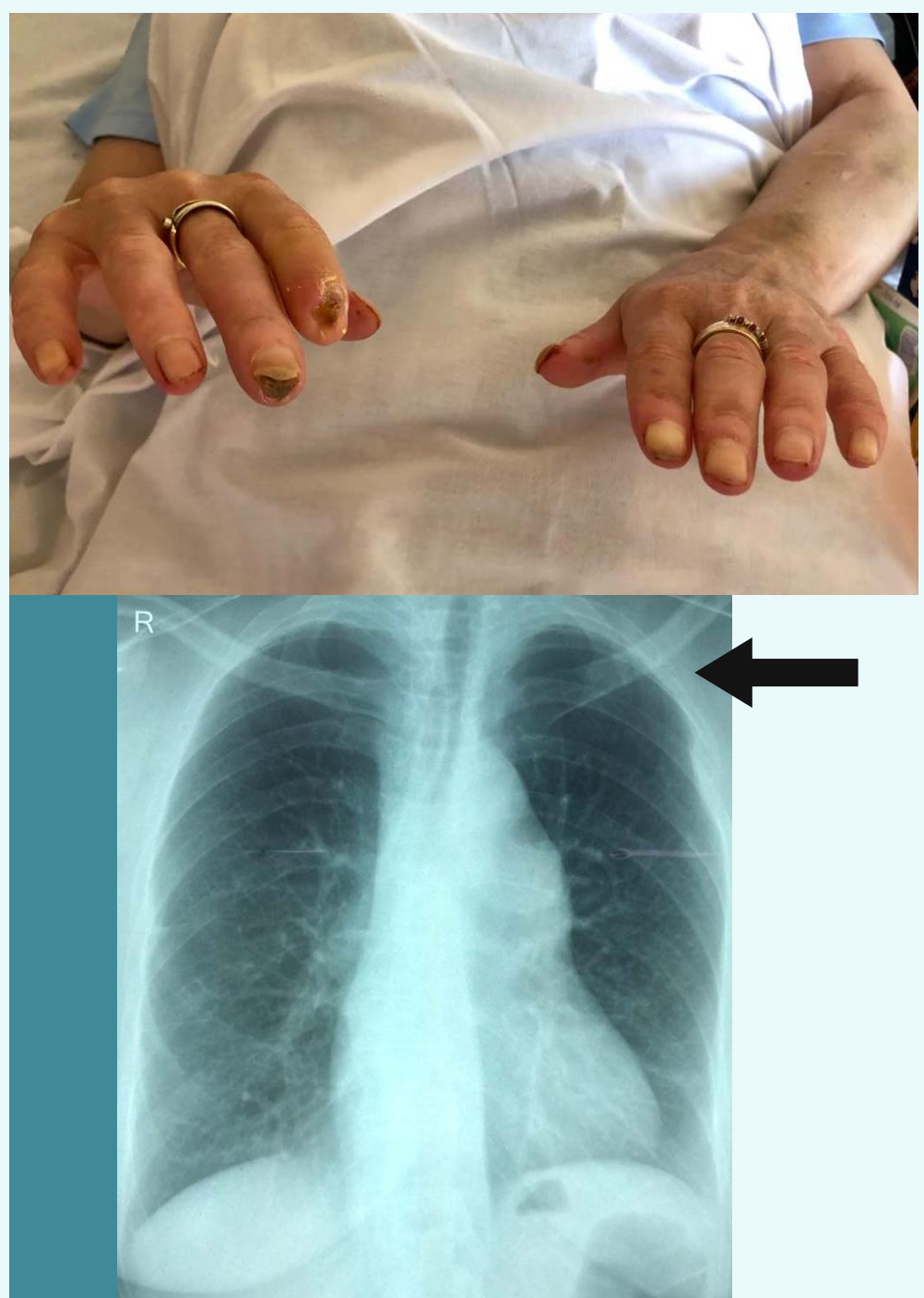

Figure1.

Fingertips necrosis

Figure 2

Chest $x$-ray: enlarged pulmonary arteries (arrow)

Figure 3.

Echocardiography: dilated left atrium

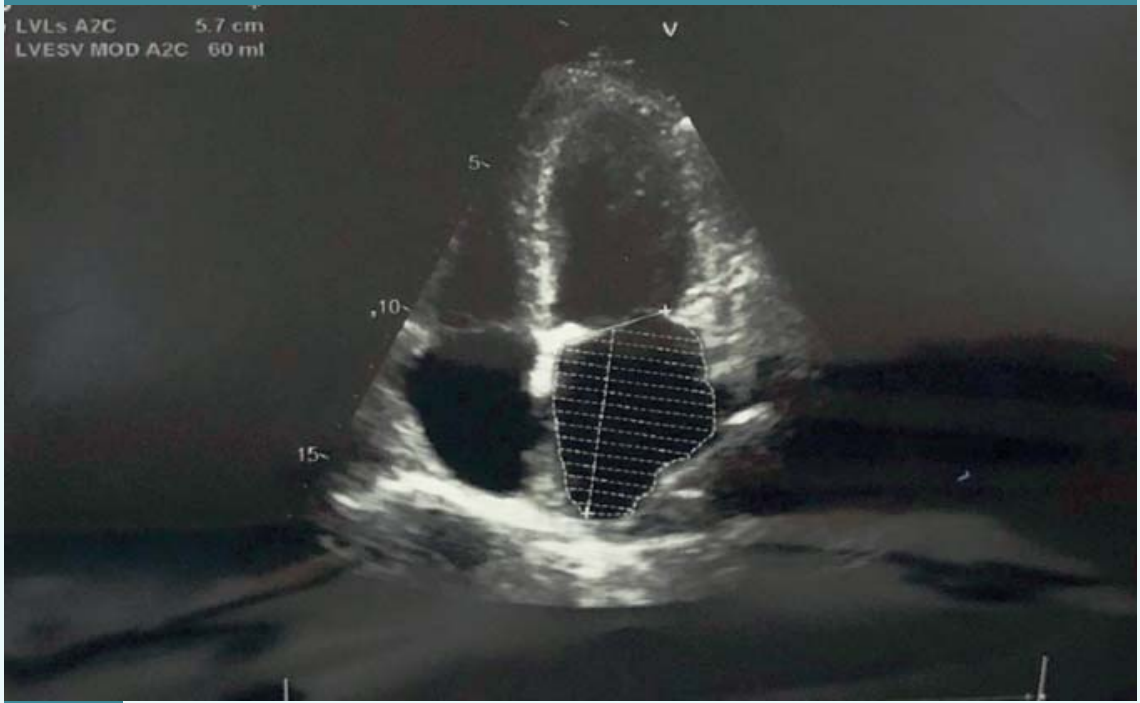


positive anti dsDNA antibodies $(67.6 \mathrm{U} / \mathrm{ml})$, positive anti-nuclear antibodies $(5.6 \mathrm{U} / \mathrm{ml})$, positive anti U1-RNP antibodies (184.6 U/ml) and positive anti Ro-SSA antibodies (200 $\mathrm{U} / \mathrm{ml}$ ). Lupus anticoagulant (LAC), anticardiolipin $\beta 2$ glycoprotein I (anti- $\beta 2 \mathrm{GPI}$ ) antibodies and anti-cardiolipin IgG/M antibodies were negative. P-ANCA, C-ANCA, anti-centromere and anti SCL-70 antibodies tests performed were all negative.

The transthoracic Doppler echocardiography performed revealed: degenerative aortic disease with large stenosis and minimal regurgitation; mild tricuspid regurgitation, moderate pulmonary regurgitation. Cardiac cavities and aorta: dilated LA, undilated LV, dilated pulmonary artery, otherwise normal size. Kinetics: normal LV and RV walls. Normal systolic function, LVEF $=70 \%$. Grade II diastolic dysfunction with pseudo normalization. Mild pulmonary hypertension, estimated systolic $\mathrm{PAP}=32 \mathrm{mmHg}$, mean PAP $=19 \mathrm{mmHG}$ (based on pulmonary regurgitation).

The arterial Doppler echography of the upper limbs showed permeable arterial axes up to the interdigital level; regarding phalanges II and III, predominantly on the right upper limb, it was observed a thick wall, with a diminished flow. The absence of distal arterial flow at the second finger of the right hand was detected.

Hands radiography detected osteolysis areas of the distal phalanges (fingers II and III, right hand and I, II, III -left hand). During hospitalization, Otorhinolaryngology opinion was taken and a diagnostic nasal endoscopy showed a large septal perforation with the absence of the cartilaginous nasal septum. CT scan of the sinuses was advised. Acquisition of native $\mathrm{CT}$ with fine sections $(0.625 \mathrm{~mm})$ and reconstructions in the bone window centered at the level of the nasal cavity and the paranasal sinuses highlighted an extended defect at the level of the cartilaginous part of the nasal septum.

Native CT with fine sections $(0.625 \mathrm{~mm})$ and reconstructions in the bone window centered at the level of the nasal cavity and the paranasal sinuses highlighted an extended defect at the level of the cartilaginous part of the nasal septum.

A biopsy was also performed, revealing extended ulceration of the superficial squamous epithelium presenting in the lamina propria, marked neutrophilic inflammatory infiltrate with areas of suppurative necrosis; one of the fragments with squamous metaplasia of the stromal mucous glands and on the surface epithelium, with reactive hyperplasia and vasculitis; adjacent fibrin-hemato-leukocyte detritus, without elements of granulomatous inflammation on the examined material.

Periungual capillaroscopy discovered moderately low capillary density, numerous dilated capillaries (without fulfilling the 

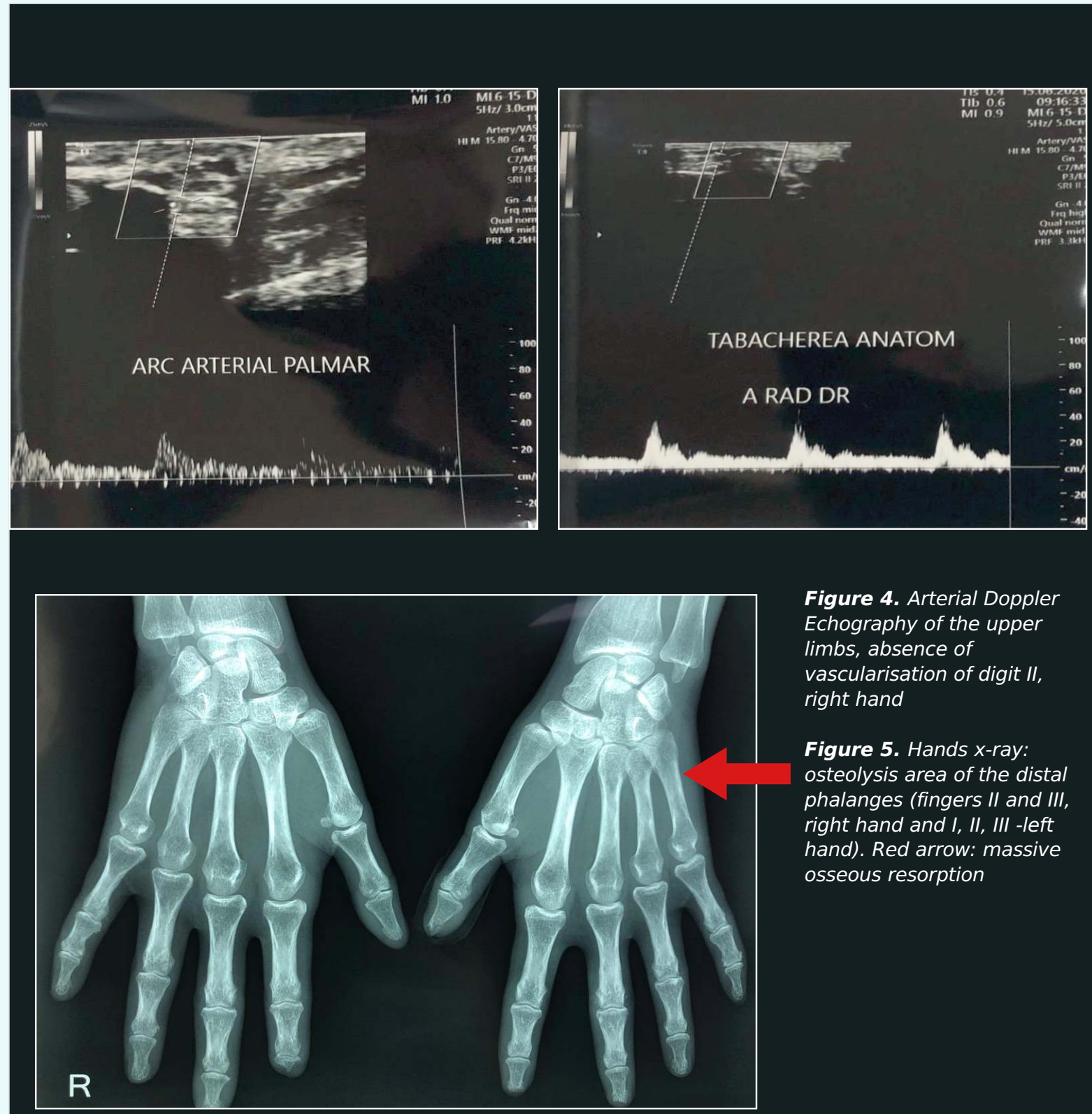

Figure 4. Arterial Doppler Echography of the upper limbs, absence of

vascularisation of digit II, right hand

Figure 5. Hands x-ray: osteolysis area of the distal phalanges (fingers II and III, right hand and I, II, III -left hand). Red arrow: massive osseous resorption

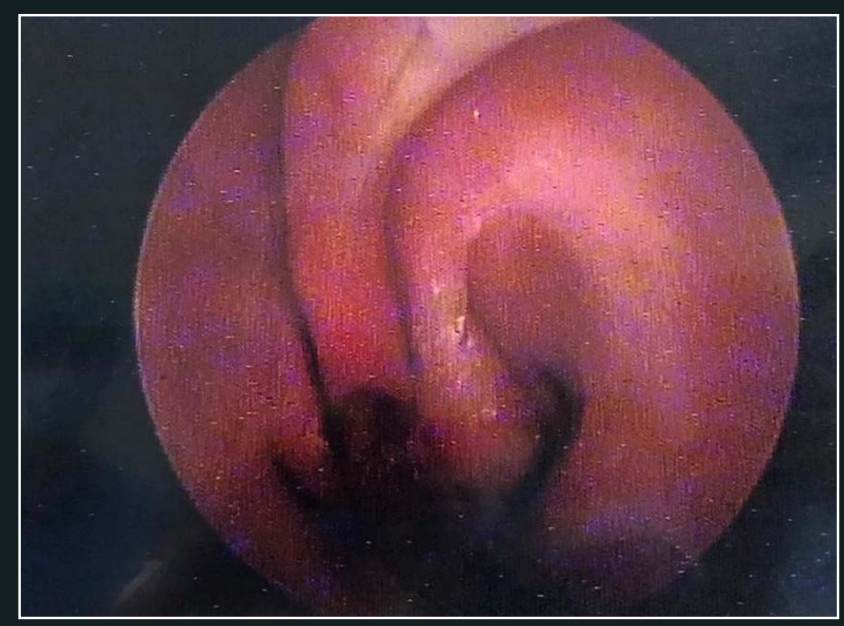

Figure 6. Large septal perforation 
megacapillary criterion), very rare old capillary hemorrhages, many bizarre capillaries (meandering), rarely branched capillaries and moderate architectural disorganization. Conclusion: morphological aspect compatible with "scleroderma like pattern".

During hospitalization, a favourable evolution was observed, but due to the progressive character of the disorder, the patient was advised to have periodic examinations. Currently, the patient is in treatment with Mycophenolate mofetil, Hydroxychloroquine, low dose corticosteroids, vasodilators (Nifedipine and Sildenafil), Aspirin and Clopidogrel.

We labeled the condition as moderate-active lupus disease (SELENA-SLEDAI = 12) with pulmonary hypertension and favourable response to oral phosphodiesterase 5 inhibitors (transition from high risk to medium risk), with acral vasculitis of the fingers and necrosis, as well as with severe epistaxis secondary to arterial vascular erosion and septal perforation.

\section{Discussion}

Given the presence of anti-U1RNP antibodies the problem of mixed connective tissue disease arises, but the patient does not meet the Alarcon-Segovia criteria, the most important element of exclusion of this condition being the presence of antibodies U1-RNP in combination with persistent and dominant autoantibodies (dsDNA, Ro,Sm) In lupus patients has been observed an association between anti-U1-RNP antibodies, Raynaud's phenomenon, capillaroscopy changes and pulmonary impairment ${ }^{(9,10)}$. On the other hand, the patient presents acral vasculitis with resorption of the terminal phalanges, thus the problem of a mixed collagenosis arises, in which SLE would be associated with scleroderma. Based on the clinical absence of sclerodactyly and negativity for scleroderma specific antibodies (anti-centromere, anti-SCL70) this diagnosis may be ruled out. Acroosteolysis's etiology is unclear but has been associated with digital ischemia or severe sensory neuropathy. It is a rare finding in patients with SLE with only a few reported cases in the literature ${ }^{(11,12)}$.

Nasal septal perforation is a rare manifestation in LES, estimated to occur in up to $5 \%$ of patients and it is thought that local vasospasm following exposure to cold inspired air could lead to ischemia in the nasal cavity like Raynaud's phenomenon with fingertip necrosis. Complete necrosis of the cartilaginous septum can also occur in various diseases, such as sarcoidosis, granulomatosis with polyangiitis as well as with cocaine use, but our patient refuted any illegal drug consumption ${ }^{(13,14)}$. Granulomatosis with polyangitis is characterized by nasal 

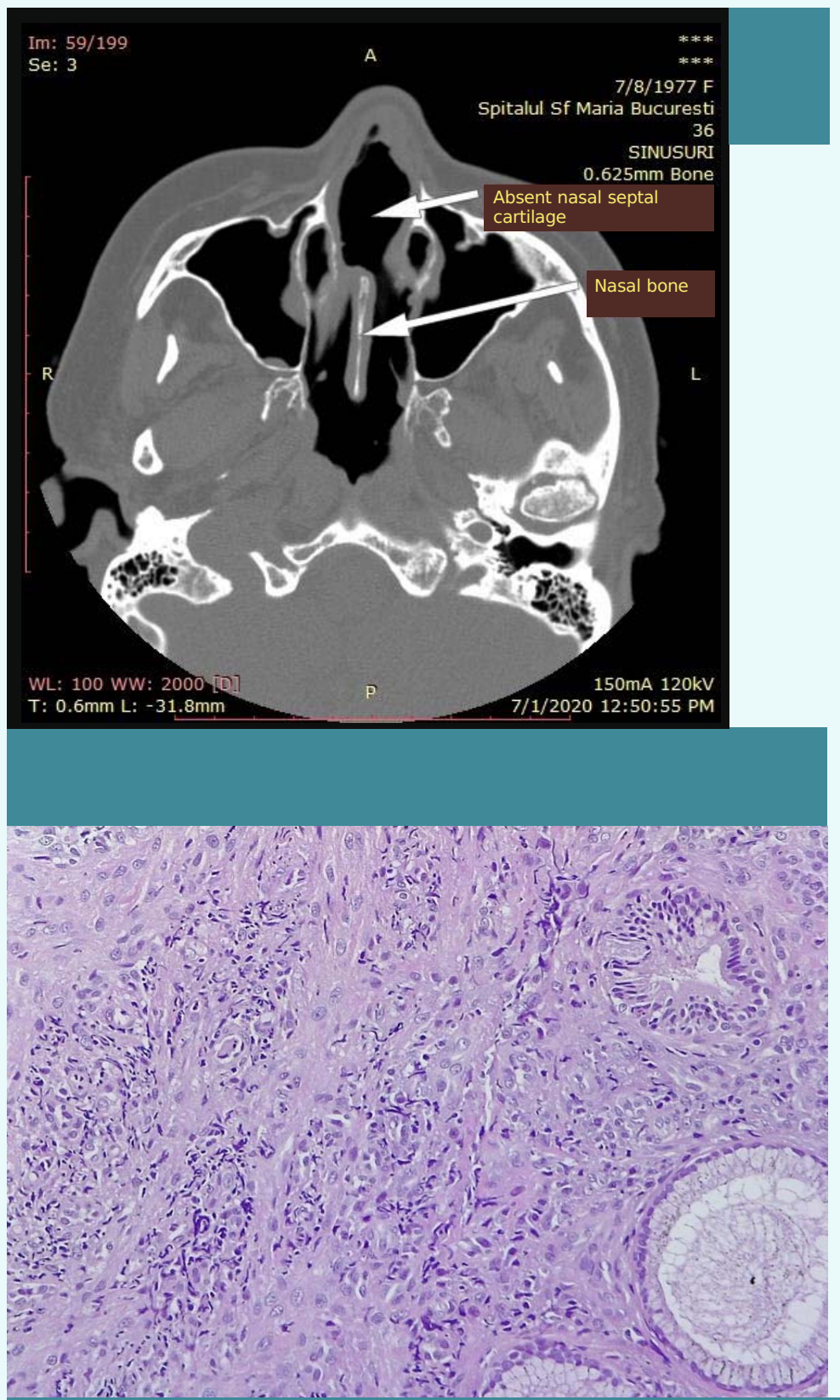

Figure 7. Native cranial CT: Absence of nasal septal cartilage

Figure 8. Biopsy of nasal septum: Vasculitis (HE examination, $20 x$ magnification)

Figure 9. Periungual capillaroscopy, 200X magnification: "Scleroderma like pattern" 


\section{INTERNAL}

\section{Clinical Cases}

obstruction and discharge, minor epistaxis, whistling with unusual crusting. But negativity for anti-c-ANCA and p-ANCA antibodies and the histopathology report that denies the presence of granulomatous inflammation disaffirms this diagnosis ${ }^{(13,14)}$.

In sarcoidosis, nasal symptoms are rare, the patients are in general good condition and approximately $80 \%$ have specific chest radiographs changes ${ }^{(14,15)}$.

$\mathrm{PAH}$ is a rare complication of SLE. The prevalence of PAH in SLE is estimated to be < $4 \%$ and there is a positive association between the presence of anti-U1-RNP antibodies and a better long-term prognosis compared with anti-U1-RNP negative patients $^{(15)}$.

\section{Conclusions}

Digital ulcers with necrosis are a common finding in systemic sclerosis, but are rare in SLE. Nasal septal perforation remains an underdiagnosed invalidating complication of lupus and treated and discovered early could have an important impact on the general health of an already burdened by disease patient.

$\mathrm{PAH}$ is a severe manifestation of SLE. An early diagnosis and treatment can positively influence the prognosis of the disease.

Although LES is no longer regarded as a rare disease, the heterogeneous spectrum of clinical picture was challenging for us mainly due to the unusual manifestations: osteolysis of the distal phalanges, nasal septal perforation and PAH.

\section{References}

1. Dall'Era M, Wofsy D. Clinical Manifestations of Systemic Lupus Erythematosus. Firestein GS, Budd RC, Gabriel SE, Maclnnes IB, O'Dell JR, eds. Kelley and Firestein's Textbook of Rheumatology. 10th ed. Philadelphia, Pa: Elsevier Saunders; 2017. 1345-67.

2. Daniel J Wallace, MD, Dafna D Gladman, MD, FRCPC, Clinical manifestations and diagnosis of systemic lupus erythematosus in adults, https://www.uptodate.com/ contents/clinical-manifestations-and-diagnosis-of-systemiclupus-erythematosus-in-adults?search = lupus\% 20erythematosus\&topicRef $=4675 \&$ source $=$ see_link

3. Botou A, Bangeas A, Alexiou l et al. Acroosteolysis. Clin Rheumatol 2017;36:914

4. L. Guillevin, Vasculopathy and pulmonary arterial hypertension, Rheumatology, Volume 48, Issue suppl_3, 1 June 2009, Pages iii54-iii57, https://doi.org/ 10.1093/rheumatology/ken484

5. A.K.ROBSON,* S.M.BURGEt \& P.R.MILLARDS, Nasal mucosal involvement in lupus erythematosus. Clin. Otolaryngol. 1992, 17, 341-343

6. Yayoi Nagai, Akira Shimizu, Mariko Suto, Setsuko Tanaka, Masahito Yasuda, Osamu Tago, Michiko Hasegawa and Osamu Ishika, Digital Gangrene in Systemic Lupus Erythematosus. Acta Derm Venereol 2009; 89: 398-401

7. Paul F Dellaripa, MD, Sonye K Danoff, MD, PhD, Pulmonary manifestations of systemic lupus erythematosus in adults, https://www.uptodate.com/ contents/pulmonary-manifestations-of-systemic-lupuserythematosus-in-adults

8. Tselios K, Gladman DD, Urowitz MB. Systemic lupus erythematosus and pulmonary arterial hypertension: links, risks, and management strategies. Open Access Rheumatol. 2016;9:1-9. Published 2016 Dec 20. 


\section{doi:10.2147/OARRR.S123549}

9. Alarcon Segovia D, Villareal M. Classification and diagnostic criteria for mixed connective tissue disease. In: Mixed Connective Tissue Disease and Anti-nuclear Antibodies, Kasukawa R, Sharp G (Eds), Elsevier, Amsterdam 1987. p.33.

10. Dima A, Jurcut C, Baicus C. The impact of anti-U1RNP positivity: systemic lupus erythematosus versus mixed connective tissue disease. Rheumatol Int. 2018;38(7):1169-1178. doi:10.1007/s00296-0184059-4

11. Rahman P, Gladman DD, Urowitz MB. Nasal-septal perforation in systemic lupus erythematosus - time for a closer look. J Rheumatol 1999;26:1854-5.

12. Bruno E, Russo $S$, Nucci R, Alessandrini $M$,
DiGirolamo S. Nasal mucosal involvement in systemic Iupus erythematosus: histopathologic and immunopathologic study. Int J Immunopathol Pharmacol 2000;13:39-42.

13. Guntupalli, L., Patel, K., Faraji, F., \& Brunworth, J. D. (2017). Autoimmune-Related Nasal Septum Perforation: A Case Report and Systematic Review. Allergy \& Rhinology. https:// doi.org/10.2500/ar.2017.8.0191

14. Willkens RF, Roth GJ, Novak A, Walike JW. Perforation of nasal septum in rheumatic diseases. Arthritis Rheum 1976; 19:119.

15. Keane MP, Lynch JP 3rd. Pleuropulmonary manifestations of systemic lupus erythematosus. Thorax 2000; 55:159. 